\title{
Evaluation of the thorax shape in the transverse plane with simple clinical technique
}

\author{
Thomasz Kotwicki , Iwona Zielinska-Kaszubowska, Andrzej Szulc \\ From 7th International Conference on Conservative Management of Spinal Deformities \\ Montreal, Canada. 20-22 May 2010
}

\section{Introduction}

Cobb angle measures the shadows of the two limit vertebrae while scoliotic deformity is a complex 3D phenomenon. There is a deficiency of simple clinical methods of thorax shape evaluation. The objective of the study was to investigate the technique measuring thorax transverse plane deformity in patients with idiopathic scoliosis.

\section{Methods}

Thirty scoliotic girls, aged $14.4 \pm 1.5$ years, single thoracic scoliosis (Lenke 1), thoracic Cobb $54.1 \pm 24.7^{\circ}$, and 30 healthy volunteers matched for sex and age (14.7 \pm 1.8 years) were examined with Martin anthropometric caliper. The length of the long and the short horizontal axes of the thorax were measured at the level of xiphoid process (upper index) and of lowest costal arch (lower index), both on maximum inspiration and expiration. Asymmetry index defined as difference of the length of the two axes expressed as percentage of the shorter one was calculated.

\section{Results}

The upper asymmetry index in the study group was $35.2 \pm$ 18.6 (inspiration) and $35.3 \pm 19.0$ (expiration), while in the control group is was $13.6 \pm 13.6$ and $13.6 \pm 13.0$, respectively, difference significant, $\mathrm{p}<0.001$. The lower asymmetry index in the study group was $26.2 \pm 12.9$ and $24.9 \pm$ 11.0 , while in the control group it was $12.5 \pm 11.7$ and $10.1 \pm 10.7$, respectively, difference significant, $\mathrm{p}<0.001$.

\section{Discussion}

Simple method of assessment of thorax asymmetry, adapted for both static and dynamic conditions may be a helpful tool for clinicians.

University of Medical Sciences, Poznan, Poland

Full list of author information is available at the end of the article

\section{Conclusions}

Thorax asymmetry index revealed significantly higher value in scoliotic patients. Asymmetry of respiratory movements was measured.

Published: 10 September 2010

doi:10.1186/1748-7161-5-S1-011

Cite this article as: Kotwicki et al:: Evaluation of the thorax shape in the transverse plane with simple clinical technique. Scoliosis 2010 5(Suppl 1): 011.
Submit your next manuscript to BioMed Central and take full advantage of:

- Convenient online submission

- Thorough peer review

- No space constraints or color figure charges

- Immediate publication on acceptance

- Inclusion in PubMed, CAS, Scopus and Google Scholar

- Research which is freely available for redistribution

Submit your manuscript at www.biomedcentral.com/submit

\section{( Biomed Central}

